\title{
CONGENITAL DIABETES MELLITUS AND NEONATAL PSEUDODIABETES MELLITUS
}

\author{
BY \\ GUNNAR ENGLESON and PER ZETTERQVIST
From Lund, Sweden
}

(RECEIVED FOR PUBLICATION JANUARY 14, 1957)

Diabetes mellitus is very rare in infants. Cases in recent years have been reported by Schwartzman, Crusius and Beirne (1947), by Bertoye and Stefani (1954) and by Keidan (1955), who reviewed the hitherto published cases of infantile diabetes. In Keidan's report 79 cases of infantile diabetes are mentioned, the neonatal cases attracting special interest on account of certain clinical characteristics.

These cases have also been published under such varying headings as congenital diabetes (Ambard, Merklen, Schmid, Wolf and Arnovljevitch, 1925; Feldmann, 1928; Nevinny and Schretter, 1930; Schretter and Nevinny, 1930; Wylie, 1953) and neonatal diabetes mellitus (Lewis and Eisenberg, 1935). Several of the congenital cases have been but insufficiently investigated, and Lawrence and McCance (1931) by an exact clinical analysis could reject a number of these as being unproved congenital cases. In most cases falling in this group (Kitselle, 1852; Morrison, 1916; Ambard et al., 1925; Feldmann, 1928; Schretter and Nevinny, 1930; Nevinny and Schretter, 1930) the diabetic mother as well as the child died at parturition.

Of proved cases of congenital diabetes there is the case reported by Guest (1949) in which diabetes was diagnosed on the ninth day after parturition, and Wylie's (1953) case discovered at the age of 2 weeks. Both of these cases resulted in permanent diabetes. The remaining cases of neonatal diabetes may be divided into two groups, the first of which may be called neonatal diabetes mellitus and into which can be put cases reported by Cuno (1910), Kochmann (1922) (these two cases are, however, doubtful) Lewis and Eisenberg (1935), Limper and Miller (1935), Devine (1938), Gans (1954), Hofman-Bang (1954) and Hickish (1956). Most of these cases of diabetes have had an abrupt course with a fatal outcome. The other group comprises diseases which differ not only from the other cases of neonatal diabetes, but also from all other instances of diabetes, because they all had a good prognosis and all were cured (Ramsey, 1926; Lawrence and
McCance, 1931; Strandquist, 1932; NawrockaKanska, 1952; Arey, 1953; Keidan, 1955; and Nelson, 1954). The majority simultaneously showed a marked infectious state which, however, was not considered of primary aetiological importance. The abnormal carbohydrate metabolism has generally lasted two or three weeks only and as a rule has yielded to insulin therapy. In a few cases a cerebrally conditioned diabetic state has been suspected (Nawrocka-Kańska, 1952; Keidan, 1955). They have been described under various designations, for example, 'temporary diabetes' (Lawrence and McCance, 1931), 'transient diabetes' (Arey, 1953; Keidan, 1955). Strandquist (1932) speaks of 'infantile glycosuria simulating diabetes' and Nelson (1954) of 'diabetes mellitus syndrome in the newborn infant'. As a common name for this condition we suggest 'neonatal pseudodiabetes mellitus'.

\section{Case Reports}

Case 1. A boy was born on February 3, 1953, at the Obstetric Department in Lund. The parents were healthy, without any diabetic heredity. The pregnancy had a normal course, but the patient was delivered by means of low forceps on account of threatening foetal hypoxia. His birth weight was $2,780 \mathrm{~g}$. (6 lb. $2 \mathrm{oz}$.) and length at birth $49 \mathrm{~cm}$. (19 in.). The child showed pronounced signs of postmaturity (Fig. 1) and was referred to stage III

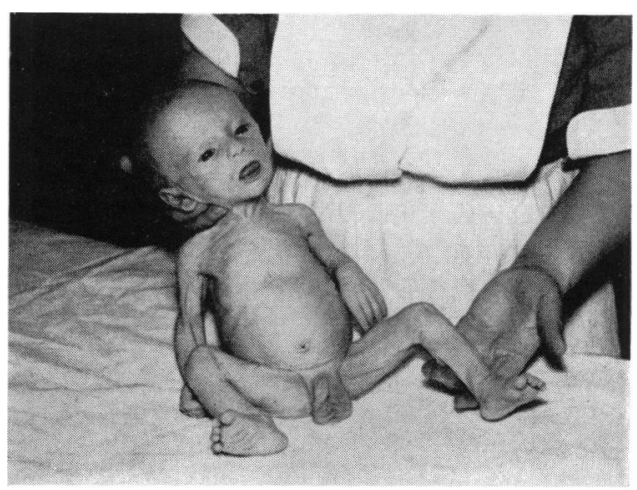

FIG. 1. 
in Clifford's (1954) classification of placental dysfunction.

The patient's weight fell to $2,300 \mathrm{~g}$. $(5 \mathrm{lb}$.) and he became cachectic, although alert. He began to vomit and on the fifth day after parturition was transferred to the Pediatric Department in Lund suspected of an endocrine-metabolic disorder. Glycosuria was proved, non-protein nitrogen was $35 \mathrm{mg} . / 100 \mathrm{ml}$. and the blood sugar was as high as $720 \mathrm{mg} . / 100 \mathrm{ml}$. In the course of the following days the blood sugar was about 400 to $500 \mathrm{mg} . / 100 \mathrm{ml}$., the glycosuria was maximally $13 \%$ but there was no ketonuria.

At first the patient was fed on small quantities of breast milk, with plenty of fluid and electrolytes. Testosterone was also administered. On this therapy the weight was maintained unchanged, the blood sugar was about $500 \mathrm{mg}$. $/ 100 \mathrm{ml}$. but the patient showed no ketosis and the general condition was surprisingly good. More breast milk was now allowed and the blood sugar was further increased to about $600 \mathrm{mg}$. $/ 100 \mathrm{ml}$. and at the same time Legal's test became positive.

At 3 weeks of age insulin therapy was instituted.

Initial laboratory tests showed eosinopenia, as well as signs of hypokalaemia. Cholesterol and phospholipids were pathologically increased, 254 and $454 \mathrm{mg} . / 100 \mathrm{ml}$. respectively. The sugar in the cerebrospinal fluid was $380 \mathrm{mg}$. $/ 100 \mathrm{ml}$. Insulin, starting with 4 i.u. NPH-insulin was given, the dose being gradually increased to 8 i.u. which was soon reduced again to 6 and finally to 4 i.u. On the second day the patient was ketone-free and the blood sugar values fell to between 250 and $300 \mathrm{mg}$. $/ 100 \mathrm{ml}$. After three weeks we changed over to the same dosage of 4 i.u. IZS (Lente) and after the lapse of a little less than a week the patient showed no sugar in the urine and the blood sugar was normal.

Two weeks later we experimentally omitted the insulin for four days. Immediately there was glycosuria, and the blood sugar rose abruptly to 350 to $400 \mathrm{mg}$. $/ 100 \mathrm{ml}$. and for this reason we again began to administer insulin in the same dosage, 4 i.u., first NPH and later, after two weeks, IZS (Lente). Some days after the change-over to IZS (Lente) the blood sugar was again normal and the urine free of sugar. The insulin was continued for another three weeks and then was discontinued for good. At that time the patient had been treated with insulin for a total of three months.

The patient was kept in hospital for three further weeks and all the time he appeared normal as regards the blood and urinary sugars. The day before he was discharged there was a mean blood sugar level of $130 \mathrm{mg} . / 100 \mathrm{ml}$. and a delta blood sugar $(=\Delta$ B.S. $)$, i.e., the difference between the maximum and the minimum values of the blood sugar curve, of $70 \mathrm{mg}$./ $100 \mathrm{ml}$. At discharge the patient had increased his weight by $3.5 \mathrm{~kg}$. and thus more than doubled his birth weight by the age of 4 months (Fig. 2).

Since his discharge in June, 1953, the patient has been examined several times. The blood sugar has been normal, there has been no glycosuria, and repeated glucose tolerance tests have proved normal too, most recently three years after discharge.

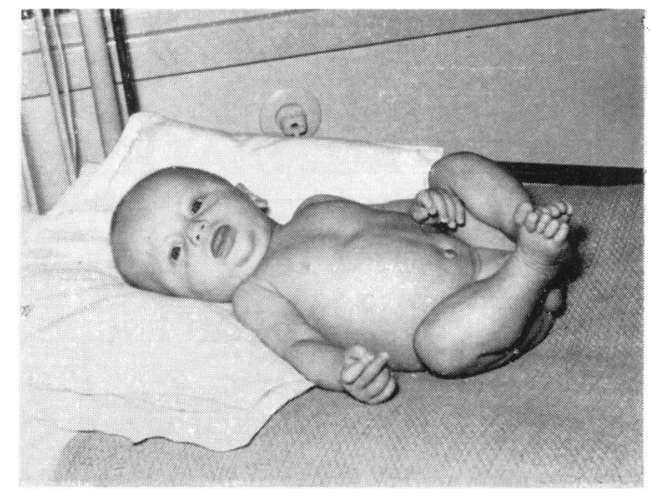

FIG. 2.

Case 2. A girl was born on April 1, 1955, at the Obstetric Department of the Centrallasarett in Vänersborg. The parents were healthy, without any diabetic heredity. The mother was healthy during pregnancy. Confinement was normal and at term. The patient measured $47 \mathrm{~cm}$. but weighed only $2,020 \mathrm{~g}$., was strikingly thin, greyish-pale and sucked poorly. The weight dropped to $1,860 \mathrm{~g}$. on the third day of life and then began to increase slowly.

On the eleventh day of life glycosuria and a urinary specific gravity as high as 1.029 was ascertained. A blood sugar test showed $400 \mathrm{mg} . / 100 \mathrm{ml}$. and during the following three days the blood sugar rose to 440,480 and $560 \mathrm{mg} . / 100 \mathrm{ml}$. An isolated test for urinary sugar at the age of 14 days showed $7 \cdot 8 \%$. No ketonuria was found. The patient was fed with breast milk in the usual quantities but fed poorly during the first two weeks.

At the age of 14 days insulin therapy was begun with 6 i.u. IZS (L.ente). In response to this the glycosuria disappeared, the specific gravity of the urine fell to about 1.005 , and the blood sugar began to fall. At the age of 19 days the insulin dosage was increased to 8 units. Afterwards the patient did well except on one occasion when she showed an insulin reaction due to an alteration in the diet owing to a misunderstanding. The patient's weight increased quickly and at the age of 3 months she weighed $3,970 \mathrm{~g}$.

Gradually the blood sugar tended to fall and simultaneously it became more stable, and the insulin dosage was reduced to 6 i.u. at the age of 37 days, to 4 units on the 57th day and finally was discontinued on the 200th day. The patient was kept at the hospital for another fortnight, and during this period the blood sugar was stable at a level of 90 to $160 \mathrm{mg}$. $/ 100 \mathrm{ml}$. A glucose tolerance test on the eighth day after discontinuing the insulin with $1 \mathrm{~g}$. glucose per $\mathrm{kg}$. body weight showed an increase of the blood sugar to $190 \mathrm{mg} . / 100 \mathrm{ml}$. after 75 minutes and a return to the level of $100 \mathrm{mg}$. $/ 100 \mathrm{ml}$. within three hours. A later test at the age of 1 year showed normal blood sugar levels and no urinary sugar. The child's length was $76 \mathrm{~cm}$. and weight $10,160 \mathrm{~g}$; somatic and mental development were quite normal. 


\section{Discussion}

It is open to discussion whether one is justified in calling these cases diabetic. Lawrence and McCance (1931) considered the diagnosis of diabetes mellitus justified if the patient showed diabetic symptoms and a glycosuria exceeding $2 \%$ or a clear recurrent hyperglycaemia above $200 \mathrm{mg} . / 100 \mathrm{ml}$. Most of the above mentioned cases directly comply with these criteria, although Keidan's (1955) cases, for example, never showed pronounced hyperglycaemia. The fact that the diabetic condition was cured in these cases challenges $a$ priori the diagnosis of diabetes mellitus. Joslin, Root, White and Marble (1952) have warned against exaggerated optimism, and claim a five-year period without recurrence as a criterion for recovery. In diabetes in children one might be justified in claiming curability even if the cases in question cannot claim a five-year period without recurrence. The three-year observation period of Case 1 of this report should be sufficient for regarding this case as recovered.

The absence of ketosis in these cases, at any rate, is remarkable, especially considering that the hyperglycaemia was often excessive. This may be explained partly by the type of diabetes in question here, and partly because a newborn infant seldom reacts with ketosis. As a general rule these cases of temporary diabetes have had but little need for insulin, and Keidan (1955) indeed asks whether insulin therapy really is necessary. In this connexion it may be said and emphasized that an attempt to discontinue it in our first case immediately resulted in aggravated conditions of the blood and urinary sugars. However, it is correct when Keidan (1955) points out that any greater insulin sensitivity is not always present initially. Because of these departures from the usual clinical picture of diabetes we would suggest the use of the term neonatal pseudo-diabetes mellitus.

An analysis of previously reported cases gives reason to suspect some of the patients to be postmature. Ramsey's (1926) case weighed 2,200 g. (about 5 lb.), Strandquist's (1932) and Arey's (1953) cases too weighed 2,200 g. each, and Keidan's (1955) patient $2,790 \mathrm{~g}$. (6 lb. $2 \mathrm{oz}$.) though born at term. One of our cases weighed $2,780 \mathrm{~g}$. and was clearly postmature, the other weighed $2,020 \mathrm{~g}$. (about $4 \frac{1}{2} \mathrm{lb}$.) though born at term. It cannot be ignored that there has been postmaturity in a number of the cases described in the literature similar to our Case 1 where there were pronounced signs of postmaturity, i.e., a placental dysfunction or insufficiency.

Arey (1953) has postulated that in his case it was a question of a hyperadrenocorticism, and Keidan (1955) suggests a hypothalamic effect in his case. Much can be said in favour of the assumption that in these patients with neonatal pseudo-diabetes mellitus we are dealing with a carbohydrate disturbance of a steroid-diabetic character. In favour of this hypothesis is the occurrence of hyperglycaemia without ketosis, the relatively weak insulin sensitivity and curability. If in these cases, as at least in one of ours, a placental dysfunction led to postmaturity in the infant it is reasonable to presume a carbohydrate of a steroid-diabetic nature. It is known that the hormonal activity in the placenta even includes secretion of corticosteroids of the '11-oxy' type. Priscilla White (1956) has thought that in these cases it is a stress or steroid type of condition.

Whether the alpha-cell dominance in the islets of the pancreas prevailing in an infant of this agewith the consequent hyperglucagonaemia - has any bearing on the occurrence of neonatal pseudodiabetes mellitus cannot be decided. A discussion of this problem may even be of a theoretical nature only. The exact mechanism of these pseudo-diabetic cases thus so far is obscure and continual investigations are of the greatest value. If the urine is systematically examined in all infants during the neonatal period more cases would no doubt be recognized.

At present it cannot be said whether an actual diabetes mellitus will develop in these patients later on. However, it seems unlikely and the case reported by Ramsey (1926) at a follow-up examination 25 years later was normal. However, it may be advisable to make control tests in connexion with infections or other conditions that might act as a releasing factor for a latent diabetic disposition.

\section{Summary}

The authors report two cases of temporary diabetes during the neonatal period. Previously reported cases of the same nature are analysed and the term 'neonatal pseudo-diabetes mellitus' for this condition is suggested.

\section{REFERENCES}

Ambard, L., Merklen, P., Schmid, Wolf and Arnovljevitch (1925). Bull. Soc. méd. Hôp. Paris, 49, 547.

Arey, S. L. (1953). Pediatrics, 11, 140.

Bertoye, P. and Stefani, A. (1954). Pédiatrie. 9, 147.

Clifford, S. H. (1954). J. Pediat., 44, 1.

Cuno. F. (1910). Jb. Kinderheilk., 71, 623.

Devine, J. (1938). Archives of Disease in Childhood 13, 189.

Feldmann, I. (1928). Z Zbl. allg Path. path. Anat., 42, 435.

Gans, B. (1954). Proc. roy. Soc. Med., 47, 132.

Guest, G. M. (1949). Acta paediat. (Uppsala), 38, 196.

Hickish, G. (1956). Brit. med. J., 1,95.

Hofman-Bang, E. (1954). Acta paediat. (Uppsala), 43, 393

Joslin, E. P., Root, H. F., White P. and Marble, A. (1952). The Treatment of Diabetes Mellitus, 9 th ed. Philadelphia.

Keidan, S. E. (1955). Archives of Disease in Childhood, 30, 291.

Kitselle, J. F. (1852). Kinderheilanstalt, 18, 313

Kochmann, R. (1922). Jb. Kinderheilk., 99, 20 
Lawrence, R. D. and McCance, R. A. (1931). Archives of Disease in Childhood, 6, 343.

Lewis, E. and Eisenberg, H. (1935). Amer. J. Dis. Child., 49, 408. Limper, M. A. and Miller, A. J. (1935). Ibid., 50, 1216.

Morrison, H. (1916). Boston med. surg. J., 175, 54.

Nawrocka-Kańska, B. (1952). Pediat. pol., 27, 1067.

Nelson, W. (1954). Textbook of Pediatrics, 6th ed., p. 1286. Philadelphia.
Nevinny, H. and Schretter, G. (1930). Arch. Gynäk., 140, 397.

Ramsey, W. R. (1926). Trans. Amer. pediat. Soc., 38, 100.

Schretter, G. and Nevinny, H. (1930). Arch. Gynak., 143, 465.

Schwartzman, J., Crusius, M. E. and Beirne, D. P (1947). Amer J. Dis. Child., 74, 587

Strandquist, B. (1932). Acta paediat. (Uppsala), 13, 421.

White, P. (1956). Personal communication.

Wylie, M. E. S. (1953). Archives of Disease in Childhood, 28, 297. 